\title{
Towards rare earth element recovery from wastewaters: biosorption using phototrophic organisms
}

\author{
Marcus Heilmann ${ }^{1} \cdot$ Roman Breiter $^{1} \cdot$ Anna Maria Becker ${ }^{1}$ (D) \\ Received: 11 March 2021 / Revised: 25 May 2021 / Accepted: 2 June 2021 / Published online: 18 June 2021 \\ (C) The Author(s) 2021
}

\begin{abstract}
Whilst the biosorption of metal ions by phototrophic (micro)organisms has been demonstrated in earlier and more recent research, the isolation of rare earth elements (REEs) from highly dilute aqueous solutions with this type of biomass remains largely unexplored. Therefore, the selective binding abilities of two microalgae (Calothrix brevissima, Chlorella kessleri) and one moss (Physcomitrella patens) were examined using Neodym and Europium as examples. The biomass of $P$. patens showed the highest sorption capacities for both REEs $\left(\mathrm{Nd}^{3+}: 0.74 \pm 0.05 \mathrm{mmol}^{*} \mathrm{~g}^{-1} ; \mathrm{Eu}^{3+}: 0.48 \pm 0.05 \mathrm{mmol}^{*} \mathrm{~g}^{-1}\right)$. A comparison with the sorption of precious metals $\left(\mathrm{Au}^{3+}, \mathrm{Pt}^{4+}\right)$ and typical metal ions contained in wastewaters $\left(\mathrm{Pb}^{2+}, \mathrm{Fe}^{2+}, \mathrm{Cu}^{2+}, \mathrm{Ni}^{2+}\right), \mathrm{which}^{2}$ might compete for binding sites, revealed that the sorption capacities for $\mathrm{Au}^{3+}\left(1.59 \pm 0.07 \mathrm{mmol}^{*} \mathrm{~g}^{-1}\right) \mathrm{and}^{\mathrm{Pb}} \mathrm{b}^{2+}(0.83 \pm 0.02$ mmol* $\mathrm{g}^{-1}$ ) are even higher. Although different patterns of maximum sorption capacities for the tested metal ions were observed for the microalgae, they too showed the highest affinities for $\mathrm{Au}^{3+}, \mathrm{Pb}^{2+}$, and $\mathrm{Nd}^{3+} . \mathrm{Nd}$-sorption experiments in the $\mathrm{pH}$ range from 1 to 6 and the recorded adsorption isotherms for this element showed that the biomass of $P$. patens has favourable properties as biosorbent compared to the microalgae investigated here. Whilst the cultivation mode did not influence the sorption capacities for the target elements of the two algal species, it had a great impact on the properties of the moss. Thus, further studies are necessary to develop effective biosorption processes for the recovery of REEs from alternative and so far unexploited sources.
\end{abstract}

\section{Key points}

- The highest binding capacity for selected REEs was registered for P. patens.

- The highest biosorption was found for Au and the biomass of the examined moss.

- Biosorption capacities of P. patens seem to depend on the cultivation mode.

Keywords Gold $\cdot$ Microalgae $\cdot$ Moss $\cdot$ REE $\cdot$ Sorption $\cdot$ Wastewaters

\section{Introduction}

Rare earth elements (REEs), consisting of lanthanum (La), the lanthanides (Ce, Pr, Nd, Pm, Sm, Eu, Gd, $\mathrm{Tb}, \mathrm{Dy}, \mathrm{Ho}, \mathrm{Er}, \mathrm{Tm}, \mathrm{Yb}, \mathrm{Lu})$ plus yttrium (Y) and scandium (Sc), are important for modern, high-tech devices and applications such as smartphones, solar cells, electric vehicles and power generation (Guyonnet et al.

Anna Maria Becker

anna.maria.becker@fau.de

1 Institute of Bioprocess Engineering, Department of Chemical and Biological Engineering, Faculty of Engineering, Friedrich-Alexander-Universität Erlangen-Nürnberg, Paul-Gordan-Straße 3, 91052 Erlangen, Germany
2015; Ambaye et al. 2020). A global demand of $160,000 \mathrm{t}$ of REEs (as their oxides) was estimated for 2016 (Hatch 2012). The growing demand for high-tech products requires an increasing availability of resources and, considering the urgent need for environmentally friendly industrial solutions, calls for sustainable production and adequate recycling. At the same time, due to the random distribution of REEs in the earth's crust, their ecological production seems to be a challenge. For example, ion-adsorbing clays, which are the main natural source of REEs, reach at best REEs contents of 0.1 weight \% (Mariano \& Mariano Jr. 2012). Therefore, their exploitation is associated with tremendous amounts of waste rock and in addition provides hazardous materials such as toxic metals, acids, fluorides and radioactive material (Öko-Institut 2011; Humphries 2013). 
Besides that, due to the risk of supply shortage and their impact on the economy, REEs were assigned by the European Commission to the list of 27 critical raw materials (European Commission Communication 2017); the USA added REEs to the list of 35 critical minerals in 2018 (US Department of Interior 2018).

In the search for potential novel REE production technologies, the sorption ability of biomass was found to be promising (Heilmann et al. 2015). Investigations of metal binding from aqueous solutions for example by algal biomass are not new; Kuyucak and Volesky (1988) reviewed early approaches for the treatment of industrial waste and process waters. So far, most developments involved microalgae for heavy metal recovery studies, where metal ions from wastewaters were removed from solutions via biosorption without additional desorbing steps (Veglio and Beolchini 1997; Wilke et al. 2006). However, biosorption is also considered one of the very promising biological methods for the recovery of metals from electronic waste, as it is very efficient and cost-effective and avoids the generation of chemical sludge (Ambaye et al. 2020; Giese 2020).

Microalgae and other phototrophic organisms, which can be cultivated in open or closed bioreactor systems, have lately received great attention due to their diversity and number of technologically interesting compounds or properties. They are not only considered a source of various native metabolites that find their use in food industry, such as natural pigments and antioxidants. Their biomass can also be used for extraction of dyes, such as malachite green or methylene blue, from wastewater (Khataee et al. 2013; Vijaraghavan et al. 2015; Ruangsomboon et al. 2013; Gupta et al. 2014).

This work focuses on biosorption abilities and binding mechanisms of selected biological species regarding REEs. In order to utilise so far unexploited and/or unconventional sources of REEs, such as mining drainage waters, seepage waters from mine dumps and mining, process waters, electrical wastes after chemical digestion and highly diluted REE solutions were particularly considered sources of the target elements in this study. Hence, the aim of this work was to characterise the sorption of selected REE representatives (Neodym and Europium) on the biomass of three biological species: Chlorella kessleri (green alga), Calothrix brevissima (cyanobacterium) and Physcomitrella patens (moss) that were identified in our previous work as promising biosorbent candidates (Heilmann et al. 2015). Sorption experiments under various conditions, such as at different $\mathrm{pH}$ values and $\mathrm{REE}$ concentrations (sorption isotherms), were conducted, and sorption capacities for other precious metals $\left(\mathrm{Au}^{3+}, \mathrm{Pt}^{4+}\right)$ as well as for metal ions typically contained in wastewaters $\left(\mathrm{Pb}^{2+}, \mathrm{Fe}^{2+}, \mathrm{Cu}^{2+}, \mathrm{Ni}^{2+}\right)$ were determined in order to evaluate the suitability of the biomass for REE recovery from different aqueous solutions.

\section{Materials and methods}

\section{Instrumentation, chemicals and organisms}

Quantification of elements from aqueous solution was performed with either by spectrophotometric assay-based on the colour reaction with xylenol orange (XO) as described by Heilmann et al. (2015) and a multilabel reader (EnSpire 2300, Perkin Elmer, USA; for concentrations $\geq 100 \mu \mathrm{M}$ of $\mathrm{Nd}^{3+}$ and $\left.\mathrm{Eu}^{3+}\right)$ - or by inductively coupled plasma atomic emission spectroscopy (ICP-AES, CIROS CCD, Spectro, Germany; for concentrations of $\mathrm{Nd}^{3+} / \mathrm{Eu}^{3+} \leq 100 \mu \mathrm{M}$ and quantification of $\mathrm{Au}^{3+}, \mathrm{Pb}^{2+}, \mathrm{Nd}^{3+}, \mathrm{Pt}^{4+}, \mathrm{Eu}^{3+}, \mathrm{Fe}^{2+}, \mathrm{Cu}^{2+}$ and $\left.\mathrm{Ni}^{2+}\right)$. For $\mathrm{pH}$ measurements, a $\mathrm{pH}$-metre $(\mathrm{pH} 510$, EUTECH Instruments, Germany/SevenGo, Mettler Toledo, USA) in combination with a microelectrode (InLab/InLab Micro, Mettler Toledo, USA) was used. All chemicals used in this study were of analytical grade and were purchased from either Fluka, Carl Roth, Merck (Germany) or Sigma-Aldrich (USA). Chemical elements for biosorption experiments were used as aqueous solutions of their chlorides $\left(\mathrm{AuHCl}_{4}, \mathrm{PtCl}_{4}\right)$, sulphates $\left(\mathrm{CuSO}_{4}, \mathrm{FeSO}_{4}, \mathrm{NiSO}_{4}\right)$ or nitrates $\left(\mathrm{Eu}\left(\mathrm{NO}_{3}\right)_{3}\right.$, $\left.\mathrm{Nd}\left(\mathrm{NO}_{3}\right)_{3}, \mathrm{~Pb}\left(\mathrm{NO}_{3}\right)_{2}\right)$. Stock solutions of target elements had a concentration of $10 \mathrm{mM}$. Chlorella kessleri SAG 211$11 \mathrm{~g}$ and C. brevissima SAG 34.79 were obtained from the SAG - Culture Collection of Algae at Göttingen University (Germany) and $P$. patens IMSC 40001 from the IMSC International Moss Stock Centre at Freiburg University (Germany). The organisms were cultivated in shake flasks (0.1-L scale), bubble columns (1-L scale) and in an airlift reactor (15-L scale) as described in the "Cultivation of biospecies" section.

\section{Cultivation of biospecies}

Table 1 gives an overview of the cultivation conditions at the different scales. Shake flask cultivation was performed under axenic conditions for up to 14 days. For the axenic biomass production at the 1-L scale, a shake flask culture was used for inoculation and the bubble column was operated for further 14 days under constant external illumination. In the case of $P$. patens, also, the biomass obtained on the 15-L scale in an internally illuminated airlift photobioreactor was used (Heining et al. 2015; Heining 2016).

Whereas biomass from shake flask cultures was employed for the determination of sorption capacities from single element solutions of $\mathrm{Nd}^{3+}$ and $\mathrm{Eu}^{3+}$ (as described in the "Cultivation of biospecies" section), all other experiments were performed with the biomass obtained from the cultivation in bubble columns $(C$. kessleri, $C$. brevissima $)$ or in the airlift photobiorector (P. patens). 
Table 1 Cultivation conditions used in this study

\begin{tabular}{|c|c|c|c|}
\hline Cultivation vessel & Scale & Medium & Conditions \\
\hline Shake flask & $0.1 \mathrm{~L}$ & $M 1^{a)}$ & $\begin{array}{l}\text { Illumination: external, } 100 \mu \mathrm{mol}^{*} \mathrm{~m}^{-2} * \mathrm{~s}^{-1} \\
\text { Temperature: RT } \\
\text { Shaking: } 40 \mathrm{rpm}, 5 \mathrm{~cm} \text { orbital motion }\end{array}$ \\
\hline Bubble column & $1 \mathrm{~L}$ & $M 1^{a)}$ & $\begin{array}{l}\text { Illumination: external, } 80 \mu \mathrm{mol}^{*} \mathrm{~m}^{-2} * \mathrm{~s}^{-1} \\
\text { Temperature: } 25^{\circ} \mathrm{C} \\
\text { Aeration: } 0.5 \mathrm{~L}^{*} \mathrm{~min}^{-1} \text { air enriched with } 3 \text { vol.- } \% \mathrm{CO}_{2}\end{array}$ \\
\hline Airlift reactor & $15 \mathrm{~L}$ & Modified Knop $^{\text {b) }}$ & $\begin{array}{l}\text { Illumination: wireless light emitters (WLE) }{ }^{\mathrm{a})} \\
60 \mu \mathrm{mol}^{*} \mathrm{~m}^{-2} * \mathrm{~s}^{-1} \\
\text { Temperature: } 25^{\circ} \mathrm{C} \\
\text { Aeration: } 0.5 \mathrm{~L}^{*} \mathrm{~min}^{-1} \text { air enriched with } 1 \text { vol.- } \% \mathrm{CO}_{2}\end{array}$ \\
\hline
\end{tabular}

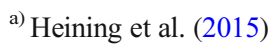

b) Heining (2016)

\section{Determination of biosorption capacity of the selected species}

The biomass of $P$. patens, $C$. kessleri and C. brevissima was lyophilised, grounded using mortar and pestle and stored at -20 ${ }^{\circ} \mathrm{C}$. For sorption experiments, biomass was weighed and placed in empty reaction tubes, stirred with a magnetic stirrer for $1 \mathrm{~h}$ in distilled water $(2 \mathrm{~mL})$ and centrifuged $(10 \mathrm{~min}, 10,000 \times \mathrm{g}$, room temperature), and the supernatant was removed. The weight of the wet biomass was recorded to determine water residue, resulting from the biomass swelling, to correct the metal ion concentrations. Various experiments were performed to investigate the adsorption behaviour of the selected biological species regarding different (target and disturbing) elements. All biosorption capacity experiments were performed in triplicates with at least one to two repetitions on different days.

First, maximum sorption capacities $\left(\mathrm{Q}_{\max }\right)$ of P. patens, C. kessleri and C. brevissima obtained from shake flask cultivation for two representatives of the REEs $\left(\mathrm{Nd}^{3+} / \mathrm{Eu}^{3+}\right)$ from single element solutions were examined. Therefore, selected biomass, prepared as described above, was placed in $2 \mathrm{~mL}$ of a $10 \mathrm{mM}$ solution of either REE $(\mathrm{pH}=5)$ to reach biomass concentrations of 5 to $20 \mathrm{~g} * \mathrm{~L}^{-1}$ and stirred with a magnetic stirrer for $24 \mathrm{~h}$ at room temperature. Various amounts of biomass were examined to appoint the maximum sorption capacity for each species. The samples were centrifuged (10 min, 10 $000 \times g$, room temperature) and the metal ion concentrations in the supernatant analysed via XO assay as described by Heilmann et al. (2015). Each sample was measured three times and sorption capacities (Q) were calculated using Eq. 1:

$Q=\frac{n_{i}-n_{f}}{m}$

where $\mathrm{n}_{\mathrm{i}}$ corresponds to the initial, $\mathrm{n}_{\mathrm{f}}$ to the final amount of the metal ion in the supernatant and $\mathrm{m}$ refers to the dry weight of the biomass used in the experiment.
Next, maximum biosorption capacities $\left(\mathrm{Q}_{\max }\right)$ for $\mathrm{Nd}^{3+}$, $\mathrm{Eu}^{3+}, \mathrm{Au}^{3+}, \mathrm{Pt}^{4+}, \mathrm{Fe}^{2+}, \mathrm{Cu}^{2+}$ and $\mathrm{Ni}^{2+}$ from single element solutions $(10 \mathrm{mM})$ were determined, according to the procedure described above, using the biomass of $C$. kessleri and $C$. brevissima cultivated in bubble columns and of $P$. patens from the $15-\mathrm{L}$ airlift reactor. These experiments were done to characterise the biosorption properties of the named species regarding the selected metal ions, to estimate the affinity of possibly competing metal ions to the selected biosorbers and to compare the sorption of REEs on the biomass resulting from different cultivation systems.

\section{Influence of the pH value on the sorption capacity of the biomass}

To investigate the influence of acidic conditions during biosorption, sorption capacities of lyophilised biomass of C. brevissima, C. kessleri and P. patens (10 $\mathrm{mg}$ respectively) for $\mathrm{Nd}^{3+}$ in the $\mathrm{pH}$ range from 1 to 6 were determined in triplicates and with at least one to two repetitions on different days. For this purpose, the biomass was prepared as described above and incubated with the respective $\mathrm{Nd}$ solution under stirring for $3 \mathrm{~h}$. The $\mathrm{pH}$ was monitored and kept constant during the experiment by adding $0.1 \mathrm{M} \mathrm{NaOH} / \mathrm{HCl}$, and each experiment was performed in triplicates. The acid/base volume added to the $\mathrm{Nd}^{3+}$ solution was registered for the correction of the metal concentration in the supernatant, which was obtained either via XO assay (Heilman et al. 2015) (for $\mathrm{pH} 3$ to 6) or via ICP-AES (for $\mathrm{pH} 1$ and 2). The equilibrium sorption capacity $\left(\mathrm{Q}_{\mathrm{eq}}\right)$ was calculated according to Eq. 1 .

\section{Adsorption isotherms}

For the evaluation of the sorption behaviour of a biomass at different $\mathrm{Nd}^{3+}$ concentrations, the biomass of all three appointed species ( $10 \mathrm{mg}$ corresponding to $5 \mathrm{~g}_{\text {biomass }}{ }^{*} \mathrm{~L}^{-1}$ ) 
was lyophylised and washed as described under the "Cultivation of biospecies" section was incubated for $3 \mathrm{~h}$ with concentrations of $\mathrm{Nd}^{3+}$ ranging from 0.5 to $6.5 \mathrm{mM}(\mathrm{n}=3)$. The $\mathrm{pH}$ during the incubation was kept constant at 5 . After the incubation, the biomass suspension was centrifuged (10 min, $10,000 \times g$, room temperature), the $\mathrm{Nd}^{3+}$ concentration in the supernatant determined using XO assay (Heilman et al. 2015) and the $\mathrm{Q}_{\mathrm{eq}}$ was calculated according to Eq. 1 .

\section{Acid/base-titrations of biomass}

Acid/base titration curves for C. brevissima, C. kessleri, and $P$. patens were prepared with biomass that was washed (as described above) and resuspended in $1 \mathrm{mM} \mathrm{NaCl}$ solution $(10 \mathrm{~mL})$. For this purpose, 25 to $475 \mu \mathrm{L}$ of either $\mathrm{HCl}$ or $\mathrm{NaOH}(0.1 \mathrm{M})$ was added and the $\mathrm{pH}$ of the supernatant was registered after exactly $2 \mathrm{~h}$ of stirring. As reference, the $\mathrm{pH}$ values of the $1 \mathrm{mM} \mathrm{NaCl}$ solution after addition of the same amounts of $\mathrm{HCl} / \mathrm{NaOH}$ were measured, and all obtained points plotted against the corresponding volume of acid/base. Finally, based on the resulting curves, the proton exchange capacity (PEC) and $\mathrm{pK}_{\mathrm{a}}$ values were calculated for each biomass with ProtoFit 2.1 (Turner and Fein 2006).

\section{Results}

\section{Sorption capacity of the selected species}

First, maximum biosorption capacities $\left(\mathrm{Q}_{\max }\right)$ of the species that were found to be promising candidates for biosorption of REEs in our previous study (Heilmann et al. 2015) were examined. Therefore, C. brevissima, C. kessleri and P. patens were cultivated under similar conditions in shake flasks. Collected, lyophilised and washed biomass was incubated with $\mathrm{Nd}^{3+} / \mathrm{Eu}^{3+}$ for $24 \mathrm{~h}$. The results are depicted in Fig. 1 . Each of the three examined species showed a higher $\mathrm{Q}_{\max }$ for $\mathrm{Nd}^{3+}$ than that for $\mathrm{Eu}^{3+}$. The highest $\mathrm{Q}_{\max \mathrm{Nd}}$ was registered for C. brevissima with $0.47 \pm 0.01 \mathrm{mmol}^{*} \mathrm{~g}^{-1}$, followed by C. kessleri $\left(0.37 \pm 0.04 \mathrm{mmol}^{*} \mathrm{~g}^{-1}\right)$ and P. patens $(0.28 \pm 0.03$ $\left.\mathrm{mmol}^{*} \mathrm{~g}^{-1}\right)$. A slightly other order was found for the second examined REE with the highest $\mathrm{Q}_{\max }$ Eu again for C. brevissima $\left(0.33 \pm 0.04 \mathrm{mmol}^{*} \mathrm{~g}^{-1}\right)$, followed by P. patens $\left(0.24 \pm 0.01 \mathrm{mmol}^{*} \mathrm{~g}^{-1}\right)$ and $C$. kessleri $(0.11 \pm$ $\left.0.01 \mathrm{mmol}^{*} \mathrm{~g}^{-1}\right)$.

Next, to evaluate the affinities of the selected biological species to various metal ions, $Q_{\max }$ values with single element solutions of $\mathrm{Au}^{3+}, \mathrm{Pb}^{2+}, \mathrm{Nd}^{3+}, \mathrm{Pt}^{4+}, \mathrm{Eu}^{3+}, \mathrm{Fe}^{2+}, \mathrm{Cu}^{2+}$ and $\mathrm{Ni}^{2+}$ were determined for biomasses of all three organisms from photobioreactors (Fig. 2). Of all ions, the highest $\mathrm{Q}_{\max }$ value was measured for $\mathrm{Au}$ and P. patens $\left(1.59 \pm 0.07 \mathrm{mmol}^{*} \mathrm{~g}^{-1}\right)$. Calothrix brevissima and C. kessleri as well showed the highest affinity for this metal ion resulting in $\mathrm{Q}_{\max }$ of $0.66 \pm$

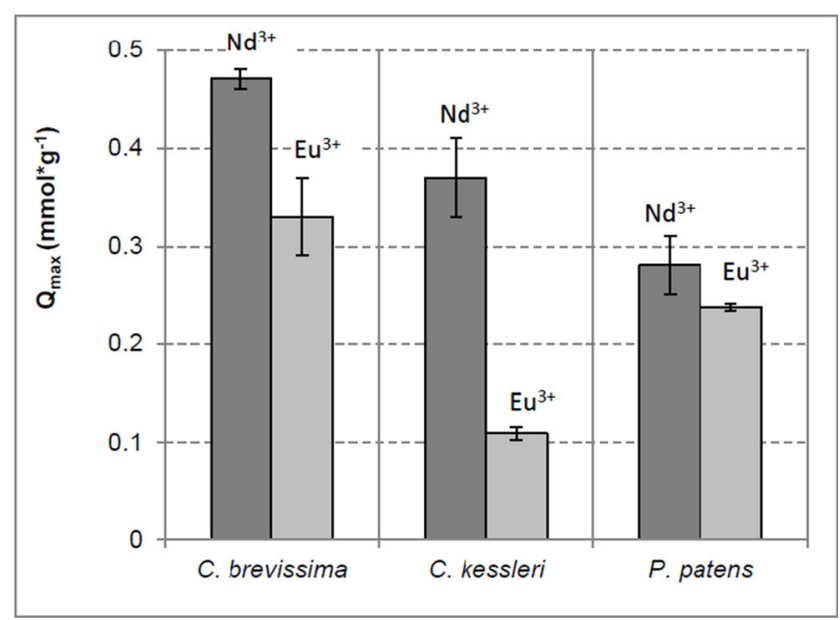

Fig. 1 Maximum sorption capacity of C. brevissima, C. kessleri and $P$. patens biomass from externally illuminated shake flask cultivation. Sorption experiment $(24 \mathrm{~h})$ performed with 5 to $20 \mathrm{~g}^{*} \mathrm{~L}^{-1}$ dried biomass and $10 \mathrm{mM}$ initial concentration of $\mathrm{Nd}^{3+} / \mathrm{Eu}^{3+}$ at room temperature and initial $\mathrm{pH}$ of $5(\mathrm{n}=3)$. Dark grey bars correspond to $\mathrm{Q}_{\max }$ of $\mathrm{Nd}^{3+}$, light grey bars to $\mathrm{Q}_{\max }$ of $\mathrm{Eu}^{3+}$

$0.01 \mathrm{mmol}^{*} \mathrm{~g}^{-1}$ and $0.65 \pm 0.1 \mathrm{mmol}^{*} \mathrm{~g}^{-1}$, respectively. The second highest binding capacity was observed for $\mathrm{Pb}$ ranging from $0.42 \pm 0.01 \mathrm{mmol}^{*} \mathrm{~g}^{-1}$ for C. kessleri to $0.83 \pm 0.02$ $\mathrm{mmol}^{* \mathrm{~g}^{-1}}$ for $P$. patens. The third highest value was registered for $\mathrm{Nd}$ and again for all three biomasses examined here with $\mathrm{Q}_{\max }$ from $0.37 \pm 0.04 \mathrm{mmol}^{*} \mathrm{~g}^{-1}$ (C. kessleri) up to 0.74 $\pm 0.05 \mathrm{mmol}^{* \mathrm{~g}^{-1}}$ (P. patens). The lowest $\mathrm{Q}_{\max }$ values of all ions were determined for $\mathrm{Ni}$, ranging from $0.008 \pm 0.004$ $\mathrm{mmol}^{*} \mathrm{~g}^{-1}$ for C. kessleri to $0.2 \pm 0.02 \mathrm{mmol}^{*} \mathrm{~g}^{-1}$ for C. brevissima. Concerning the investigated biomasses, P. patens showed binding capacities that were up to 2.4 times higher $(\mathrm{Au})$ than the ones of the other two species. Most of the other metal ions tested here were also bound more effectively by $P$. patens than by either of the two remaining biosorbents, with the exception of $\mathrm{Cu}$ and Ni. Surprisingly, the sorption capacities of $P$. patens for $\mathrm{Nd}^{3+}$ and $\mathrm{Eu}^{3+}$ in this second experiment were 2.6-fold and twofold higher than in the first experiment. The obvious difference between these two experiments was the method of biomass production suggesting that the moss biomass characteristics differed significantly between shake flask and WLE airlift reactor culture. A comparable discrepancy was not observed for the algal/ cyanobacterial biomass from shake flasks and bubble columns.

\section{Characterisation of the biosorption of REEs by the biomass of $C$. brevissima, $C$. kessleri and $P$. patens}

\section{Adsorption isotherms at constant $\mathrm{pH}$}

For the intended applications, such as biosorption from wastewater and seepage water, high sorption capacities already at low concentrations of the respective ions are desirable. Thus, 


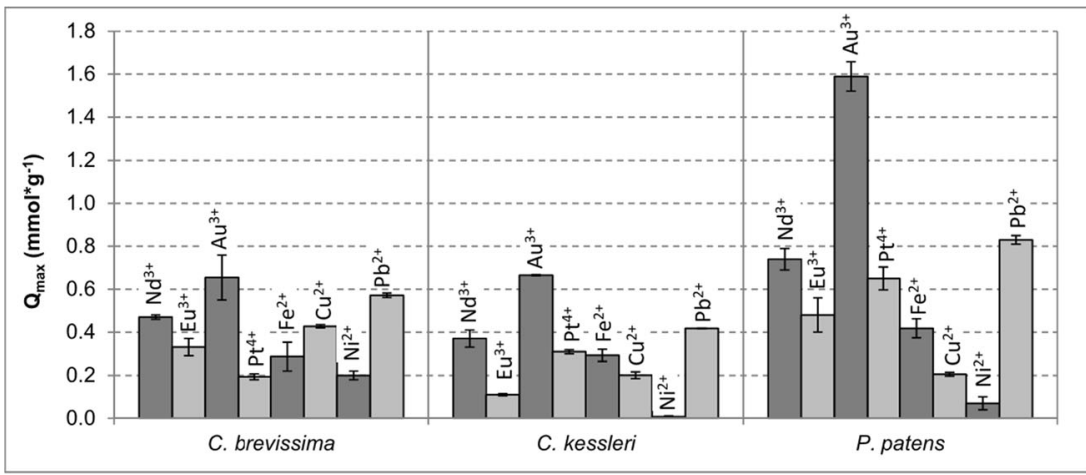

Fig. 2 Sorption capacities of C. brevissima, C. kessleri and P. patens for different metal ions from single aqueous element solutions of the target ion. Sorption experiment $\left(24 \mathrm{~h}\right.$ ) performed with $5 \mathrm{~g}^{*} \mathrm{~L}^{-1}$ of dried biomass and $10 \mathrm{mM}$ initial concentration of respective metal ions at room

sorption isotherms must be considered to select a suitable biosorber material. For this reason, the sorption of $\mathrm{Nd}^{3+}$ at various initial concentrations at room temperature and constant $\mathrm{pH}$ of the solution $(\mathrm{pH}=5)$ by the biomass of $C$. brevissima, $C$. kessleri and P. patens was registered. The resulting adsorption isotherms were fitted with functions described by Langmuir (1932) or Freundlich (1906) that are described by equations given below (Eqs. 2 and 3 ).

Equation 2 Langmuir's isotherm with $\mathrm{Q}=$ sorption capacity; $\mathrm{Q}_{\max }=$ maximum sorption capacity; $\mathrm{c}=$ concentration of $\mathrm{Nd}^{3+} ; \mathrm{b}=$ specific constant, depending on temperature and adsorption enthalpy.

$Q=\frac{Q_{\max } * c}{b+c}$

Equation 3 Freundlich's isotherm with $\mathrm{Q}=$ sorption capacity; $\mathrm{c}=$ concentration of $\mathrm{Nd}^{3+} ; \mathrm{a}, \mathrm{m}=$ specific constants, depending on the system.

$Q=a^{*} c^{1 / m}$

As the $\mathrm{pH}$ can be crucial in evaluating adequate sorption capacities, adsorption isotherms were recorded at a strictly defined $\mathrm{pH}$ value of 5 , close to the original $\mathrm{pH}$ of the $\mathrm{Nd}^{3+}$ stock solution $(10 \mathrm{mM}, \mathrm{pH}=5.2) . \mathrm{Nd}^{3+}$ adsorption isotherm curves are presented in Fig. 3. The isotherm for P. patens showed Langmuir-like behaviour, displaying a very steep slope at low $\mathrm{Nd}$ equilibrium concentrations $(0.0095-0.3$ $\mathrm{mM}$ ) and reaching its maximum at $0.75 \mathrm{mmol}^{*} \mathrm{~g}^{-1}$ already around $0.3 \mathrm{mM}$ of $\mathrm{Nd}^{3+}$, which corresponds very well with the $\mathrm{Q}_{\max }$ of $\mathrm{Nd}^{3+}$ obtained with the same biomass and described above (the "Sorption capacity of the selected species" section). The isotherm of $C$. brevissima could also be fitted well to the Langmuir function and showed a steep initial slope reaching $\mathrm{Q}_{\max }$ of $0.49 \pm 0.09 \mathrm{mmol}^{*} \mathrm{~g}^{-1}$, also being in a good agreement with the maximum sorption capacities obtained in both previous experiments. In contrary, the adsorption temperature and initial $\mathrm{pH}$ of $5(\mathrm{n}=3)$. The biomass of $P$. patens was obtained from an internally illuminated airlift culture (Heining et al. 2015); those of $C$. brevissima and $C$. kessleri were generated in externally illuminated bubble columns

isotherm for $\mathrm{Nd}^{3+}$ and $C$. kessleri could be better fitted with Freundlich's isotherm.

\section{Biosorption from solutions of various $\mathrm{pH}$}

Due to precipitation and sedimentation of most REE hydroxides at values above $\mathrm{pH} 7$, increased metal ion concentrations are to be expected particularly in acidic wastewater samples. Therefore, the biosorption of $\mathrm{Nd}^{3+}$ at different $\mathrm{pH}$ values ranging from 1 to 6 was examined for the biomasses of C. brevissima, C. kessleri and P. patens (Fig. 4). As depicted in Fig. 4, expectedly for all tested biomasses, the $Q_{\text {eq, Nd }}$ increased with increasing $\mathrm{pH}$, showing however different initial slopes. Whereas the sorption capacities determined for $P$. patens in this experiment reached their maximum already around $\mathrm{pH}$ of $3\left(0.72 \pm 0.03 \mathrm{mmol}^{*} \mathrm{~g}^{-1}\right)$ and remained nearly

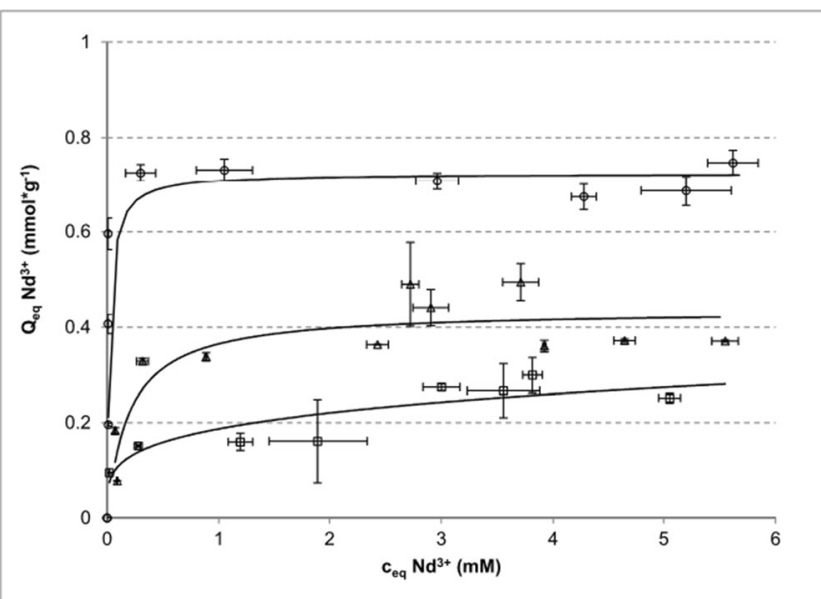

Fig. 3 Sorption isotherms recorded at constant $\mathrm{pH}$ of the $\mathrm{Nd}^{3+}$-solution for C. brevissima (triangles), C. kessleri (squares) and P. patens (circles). $\mathrm{Nd}^{3+}$ solutions of initial concentrations ranging from 0.5 to $6.5 \mathrm{mM}$ were incubated (room temperature, $3 \mathrm{~h}, \mathrm{pH}$ 5) with dried biomass of the investigated species $\left(10 \mathrm{mg}\right.$ corresponding to $\left.5 \mathrm{~g}_{\text {biomass }} * \mathrm{~L}^{-1}\right)(\mathrm{n}=3)$. The biomass of $C$. brevissima and $C$. kessleri was cultivated in bubble columns, whereas $P$. patens was obtained from cultivation in a WLE airlift reactor (Heining et al. 2015) 


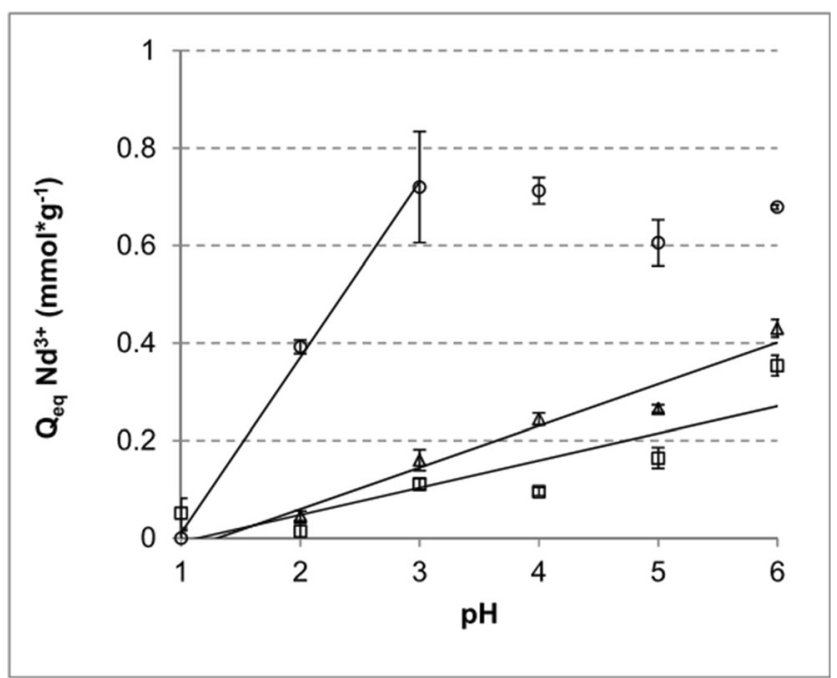

Fig. 4 Equilibrium sorption capacities for $\mathrm{Nd}^{3+}\left(\mathrm{Q}_{\text {eq, Nd }}\right)$ at different $\mathrm{pH}$ values ( $\mathrm{pH} 1-\mathrm{pH}$ 6) of a $\mathrm{Nd}$ solution for C. brevissima (triangles), $C$. kessleri (squares) and P. patens (circles). Lyophied biomass of the three species $\left(10-30 \mathrm{~g} * \mathrm{~L}^{-1}\right)$ was incubated with Nd-solutions for $3 \mathrm{~h}$ at room temperature and washed in distilled water prior to the sorption experiments $(\mathrm{n}=3)$; C. brevissima and C. kessleri - PSM cultures, P. patens - WLE airlift culture (Heining et al. 2015)

constant up to $\mathrm{pH}$ 6, positive, linear correlations between $\mathrm{Q}_{\mathrm{eq}}$, $\mathrm{Nd}$ and increasing $\mathrm{pH}$ values were observed for C. brevissima and $C$. kessleri with the highest sorption values reached only at $\mathrm{pH} 6\left(0.43 \pm 0.14 \mathrm{mmol}^{*} \mathrm{~g}^{-1} ; 0.35 \pm 0.14 \mathrm{mmol}^{*} \mathrm{~g}^{-1}\right.$, respectively), again corresponding well with the previously obtained data.

\section{Proton exchange capacity of the selected species}

To evaluate the proton exchange capacity (PEC) and to help to assess the binding mechanism of REE sorption on the biomass, acid-base titration studies were performed with the lyophilised biomass of $P$. patens, C. kessleri and C. brevissima. The biomass was washed with deionised water and resuspended in $\mathrm{NaCl}$ solution; hence, the protonation grade at the starting point of titration remained unchanged. The titration curves of the dried biomass of these three species are shown in Fig. 5. The protonation grades of the examined biomasses were calculated based on the difference between the $\mathrm{pH}$ of the reference (without biomass) and the $\mathrm{pH}$ of the biomass suspension prior to the base/acid addition. The respective PEC values were calculated based on the titration endpoints and the resulting $\mathrm{pK}_{\mathrm{a}}$ values using ProtoFit 2.1 (Turner and Fein 2006). Chemical properties calculated from titration data (Fig. 5) are shown in Table 2. The highest PEC was calculated for the biomass of $P$. patens $\left(3.48 \mathrm{mmol}^{*} \mathrm{~g}^{-1}\right)$, followed by $C$. brevissima $\left(2.95 \mathrm{mmol}^{*} \mathrm{~g}^{-1}\right)$ and $C$. kessleri $\left(2.51 \mathrm{mmol}^{*} \mathrm{~g}^{-1}\right)$ with protonation grades of 67,79 and 100 $\%$, respectively. As the actual $\mathrm{pK}_{\mathrm{a}}$ value of a functional group depends on the location in the macromolecular structure and chemical surrounding, definite classifications of the functional groups involved in sorption were not possible. On the other hand, it is highly probable that carboxy groups were found in all the species tested with $\mathrm{pK}_{\mathrm{a}}$ values ranging from 4.2 (C. brevissima) to 5.5 (P. patens), indicating terminal carboxyl groups of peptides and glycoproteins. Hydroxy groups could be determined as more acidic ones, e.g., terminal hydroxyl groups in glycoproteins $\left(\mathrm{pK}_{\mathrm{a}} 6.3\right.$ and 8.3) and more basic ones in phenolic side chains $\left(\mathrm{pK}_{\mathrm{a}} 10.4\right.$ to 11.3). Moreover, $\mathrm{pK}_{\mathrm{a}}$ values around 11 suggest $\alpha$-amino groups and $\mathrm{pK}_{\mathrm{a}}$ values of 6.3 phosphate groups.

\section{Discussion}

\section{Sorption capacity of the selected species}

The highest sorption capacities from a single ion metal solution of the selected REE representatives $\left(\mathrm{Nd}^{3+} / \mathrm{Eu}^{3+}\right)$ were found in this study for the moss biomass of P. patens reaching up to $0.75 \mathrm{mmol}^{* \mathrm{~g}^{-1}}$ for $\mathrm{Nd}^{3+}$ and $0.48 \mathrm{mmol}^{* \mathrm{~g}^{-1}}$ for $\mathrm{Eu}^{3+}$. This $\mathrm{Nd}$ value corresponds well with the $\mathrm{Q}_{\max , \mathrm{Nd}}$ reported in our previous study (Heilmann et al. 2015). In both cases, the results were obtained using biomass that was cultivated in an innovative internally illuminated photobioreactor (Heining et al. 2015). Surprisingly, the biomass of the same moss raised in the identical culture medium but in shake flasks with external illumination showed a $Q_{\max }$ of only $0.28 \pm 0.03 \mathrm{mmol}^{*} \mathrm{~g}^{-1}$ for $\mathrm{Nd}^{3+}$ and $0.24 \pm 0.01 \mathrm{mmol}^{*} \mathrm{~g}^{-1}$ for $\mathrm{Eu}^{3+}$. The latter capacities were thus even lower than those found for the two microalgae examined here. The biomass of $C$. brevissima and C. kessleri produced in shake flasks and in bubble columns showed very similar sorption capacities for $\mathrm{Nd}^{3+} / \mathrm{Eu}^{3+}$ of about $0.5 / 0.3 \mathrm{mmol}^{*} \mathrm{~g}^{-1}$ for the first and $0.4 / 0.1 \mathrm{mmol}^{*} \mathrm{~g}^{-1}$ for the second species. Thus, these data suggest that the cultivation mode does not strongly influence the biosorption properties of either the cyanobacterium or of the green alga, but rather those of the moss species $-P$. patens. The higher sorption capacity of the moss biomass from WLE airlift cultivation might possibly be explained by an increased biomass surface and thus more exposed binding sites, due to the specific lightning mode delivered by the WLE and by the continuous mechanical stress during this cultivation.

Independent from the experimental setup, all three examined biological species can bind $\mathrm{Nd}$ more effectively than $\mathrm{Eu}$. Although only few reports are available on sorption of REEs on phototrophic species, making comparisons quite difficult, some data for example for bacteria, yeast and sea weeds have already been published. Palmieri et al. (2000) compared biosorption of $\mathrm{Nd}$ from acidic solutions ( $\mathrm{pH}$ of 1.5 ) by three biological species: a microalga (Monoraphidium sp.), baker's yeast and an ascomycetous fungus (Penicillium sp.). The authors reported higher sorption capacities of $1511 \mathrm{mg}^{*} \mathrm{~g}^{-1}(10$ 
Table 2 Chemical properties of biomass binding sites, determined by titration of dry biomass and calculated via ProtoFit 2.1

\begin{tabular}{|c|c|c|c|c|}
\hline & C. brevissima ${ }^{\mathrm{a})}$ & C. kessleri $^{\mathrm{a})}$ & P. patens $\mathrm{s}^{\mathrm{b}}$ & Functional group \\
\hline $\operatorname{PEC}\left(\mathrm{mmol}^{*} \mathrm{~g}^{-1}\right)^{\mathrm{c})}$ & 2.95 & 2.51 & 3.48 & - \\
\hline Protonation rate $(\%)$ & 79 & 100 & 67 & - \\
\hline $\mathrm{Q}_{\max , \mathrm{Nd}}\left(\mathrm{mmol}^{*} \mathrm{~g}^{-1}\right)$ & 0.47 & 0.37 & 0.75 & - \\
\hline $\mathrm{Q}_{\max , \mathrm{Eu}}\left(\mathrm{mmol}^{*} \mathrm{~g}^{-1}\right)$ & 0.33 & $<\operatorname{LOD}^{\mathrm{d})}$ & 0.48 & - \\
\hline $\mathrm{pK}_{\mathrm{a}} 1$ & 4.2 & 4.8 & 4.3 & Carboxy group \\
\hline $\mathrm{pK}_{\mathrm{a}} 2$ & 11.3 & 10.4 & 11.0 & $\alpha$-Amino group/phenolic $\mathrm{OH}$ \\
\hline $\mathrm{pK}_{\mathrm{a}} 3$ & / & 6.3 & 6.3 & Phosphate/hydroxy group \\
\hline $\mathrm{pK}_{\mathrm{a}} 4$ & / & 8.3 & 5.5 & Carboxy group/hydroxy group \\
\hline
\end{tabular}

$\left.\mathrm{mmol}^{*} \mathrm{~g}^{-1}\right), 313 \mathrm{mg}^{*} \mathrm{~g}^{-1}\left(2.2 \mathrm{mmol}^{*} \mathrm{~g}^{-1}\right)$ and $178 \mathrm{mg}^{*} \mathrm{~g}^{-1}$ $\left(1.2 \mathrm{mmol}^{*} \mathrm{~g}^{-1}\right)$, respectively than we found here. Tunali and Yenigun (2021) found a $\mathrm{Q}_{\mathrm{Nd}}$ of about $240 \mathrm{mg}^{*} \mathrm{~g}^{-1}$ (1.7 mmol* $\mathrm{g}^{-1}$ ) for dried biomass of Chlorella vulgaris, and data compiled by Andrès et al. (2003) shows a $\mathrm{Q}_{\mathrm{Nd}}$ of 1.1 $\mathrm{mmol}^{*} \mathrm{~g}^{-1}$ and a $\mathrm{Q}_{\mathrm{Eu}}$ of $0.83 \mathrm{mmol}^{* \mathrm{~g}^{-1}}$ for bacteria and yeast, hence slightly higher values but more or less in the same range as determined in this study. Kücüker et al. (2017) reported a maximum $\mathrm{Nd}$ uptake at $\mathrm{pH}$ of 5 and $35^{\circ} \mathrm{C}$ of $157.4 \mathrm{mg}^{*} \mathrm{~g}^{-1}\left(1.1 \mathrm{mmol}^{*} \mathrm{~g}^{-1}\right)$ using the biomass of Chlorella vulgaris. Furthermore, the examination of the binding of REEs by seaweed revealed a $\mathrm{Q}_{\mathrm{Nd}}$ of $0.7 \mathrm{mmol}^{*} \mathrm{~g}^{-1}$ and a $Q_{E u}$ of $0.63 \mathrm{mmol}^{*} \mathrm{~g}^{-1}$, thus being in a good agreement with the data presented here (Oliveira and Garcia Jr. 2009). In good correspondence with our results, the application of phosphorylation (using cyclo-triphosphate) to dry baker's yeast investigated by Ojima et al. (2019) resulted in an improved capacity for $\mathrm{Nd}\left(0.77 \mathrm{mmol}^{*} \mathrm{~g}^{-1}\right)$, whilst it was much lower for untreated yeast $\left(0.08 \mathrm{mmol}^{*} \mathrm{~g}^{-1}\right)$. Interestingly, similarly to our data, also the latter two groups found slightly lower binding capacities of the investigated biomass for $\mathrm{Eu}$ in comparison to that for Nd. To the best of our knowledge, sorption of REEs onto the surface of a moss has not yet been described by other groups in the literature. Nevertheless, sorption capacities of $\mathrm{Zn}^{2+}$ onto several moss species were investigated by various researchers reporting values for $\mathrm{Q}_{\max , \mathrm{Zn}}$ ranging from $0.08 \mathrm{up}$ to $0.93 \mathrm{mmol}^{*} \mathrm{~g}^{-1}$ dry weight (dw) on moss that was collected in natural habitats (Gonzalez et al. 2016, Kłos et al. 2014, Martins et al. 2004, Zhang and Banks 2005). With moss, the moss that was cloned from a single native sample and cultivated axenically under standardised conditions a $Q_{\max }, Z_{n}$ of up to $4.6 \mathrm{mmol}^{*} \mathrm{~g}_{\mathrm{dw}}^{-1}$ was observed (Gonzalez et al. 2016).

By expanding our investigations to the biosorption of additional metals and other possibly disturbing biosorption metal ions, further interesting aspects could be observed. The overall highest $\mathrm{Q}_{\max }$ in this work was found for gold and P. patens $\left(1.59 \mathrm{mmol}^{*} \mathrm{~g}^{-1}\right)$. The sorption capacity for $\mathrm{Au}$ of $P$. patens was about 2.4-fold higher compared to that of C. brevissima or C. kessleri. For comparison, Itouga et al. (2017) described the sorption capacity for Au and Funaria

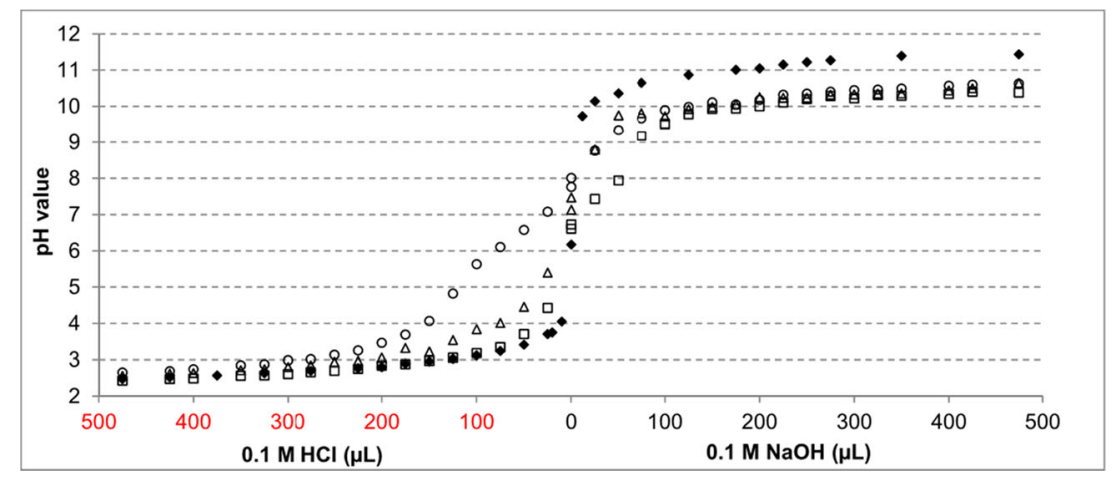

Fig. 5 Acid-base titration curves of dry biomass of C. brevissima (triangles), C. kessleri (squares) and P. patens (circles) and without biomass (diamonds). Base/acid $(0.1 \mathrm{M} \mathrm{NaOH} / 0.1 \mathrm{M} \mathrm{HCl})$ was added to dried and with ultrapure water washed biomass $(2 \mathrm{~mL}, 1 \mathrm{~h}$, room temperature, mixing) of the selected species $(10 \mathrm{mg}$ ) suspended in 10 $\mathrm{mL}$ of $1 \mathrm{mM} \mathrm{NaCl}$; $\mathrm{pH}$ values were measured $2 \mathrm{~h}$ after addition of titration agent $(\mathrm{n}=1) ; C$. brevissima and $C$. kessleri - bubble column cultures, $P$. patens - WLE airlift culture (Heining et al. 2015) 
hygrometrica to be $0.6 \mathrm{mmol}^{*} \mathrm{~g}_{\mathrm{dw}}^{-1}$, corresponding well with the values determined for $C$. brevissima and $C$. kessleri in this study. Furthermore, Tunali and Yenigun (2021) also reported for sorption experiments performed at similar conditions as in this studies and with the biomass of Chlorella vulgaris an $\mathrm{Au}$ uptake of $165.5 \mathrm{mg}^{*} \mathrm{~g}^{-1}\left(0.84 \mathrm{mmol}^{*} \mathrm{~g}^{-1}\right)$.

The second highest maximum sorption capacity, again for all three species, was observed for $\mathrm{Pb}$ resulting in $\mathrm{Q}_{\max }$ of 0.8 $\mathrm{mmol}^{*} \mathrm{~g}^{-1}$ for $P$. patens, $0.6 \mathrm{mmol}^{*} \mathrm{~g}^{-1}$ for $C$. brevissima and $0.4 \mathrm{mmol}^{*} \mathrm{~g}^{-1}$ for $C$. kessleri. In comparison, previous investigations regarding the biosorption of $\mathrm{Pb}$ (II) on various, mostly collected, moss samples report values for $\mathrm{Q}_{\max }$, $\mathrm{Pb}$ ranging

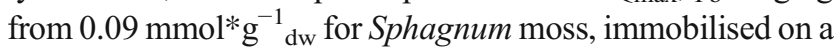

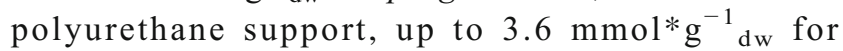
$F$. hygrometrica collected in Japan and grown on agar, thus indicating that sorption efficiencies are strongly depended on the species under investigation (Bulgariu et al. 2008, Itouga et al. 2017, Okoli et al. 2017, Zhang and Banks 2005). As with $\mathrm{Nd}$ and $P$. patens, the phosphorylated dry baker's yeast mentioned above also showed very similar sorption capacity for $\mathrm{Pb}^{2+}\left(0.91 \mathrm{mmol}^{*} \mathrm{~g}^{-1}\right)$ (Ojima et al. 2019), which was slightly higher than the value recorded for $\mathrm{Nd}$ in our work.

The comparison of the affinities of various metal ions to the here selected species revealed that $\mathrm{Ni}$ is the least effectively bound element. Whilst the highest capacities were registered for $\mathrm{Au}, \mathrm{Pb}$ and $\mathrm{Nd}$ with $\mathrm{Q}_{\max }$ values following the same order for all tested biosorbents $\left(\mathrm{Q}_{\max \mathrm{Au}}>\mathrm{Q}_{\max \mathrm{Pb}}>\mathrm{Q}_{\max \mathrm{Nd}}\right)$, no such clear trends could be observed for the other metal ions. For example, $\mathrm{Q}_{\max }$ for P. patens (WLE airlift cultivation) displays a sequence with $\mathrm{Au}>\mathrm{Pb}>\mathrm{Nd}>\mathrm{Pt}>\mathrm{Eu}>\mathrm{Fe}>$ $\mathrm{Cu}>\mathrm{Ni}$ which is different from that of $C$. brevissima $\mathrm{Au}>\mathrm{Pb}$ $>\mathrm{Nd}>\mathrm{Cu}>\mathrm{Eu}>\mathrm{Pt} \approx \mathrm{Ni}$. Such differences in biomass affinities of various species for different metal ions are important and can be further used for development of biosorptionbased recovery processes, for instance to successively bind target/disturbing ions by using various sorbent materials. As lead, iron, copper and nickel are the most common elements in wastewaters, either a selected biosorber should not bind them or they have to be removed prior the application of biosorption. Furthermore, the here observed differences between various affinities indicate that multiple and/or different sorption mechanisms play roles in their binding on the biomass.

\section{Characterisation of biosorption of REEs by the selected species}

Isotherms were fitted to the data obtained for the adsorption of $\mathrm{Nd}$ on biomass of P. patens, C. brevissima and C. kessleri. The Langmuir function was suitable to describe the behaviour of the first two species, whereas the Freundlich's isotherm was better suited in case of $C$. kessleri. The isotherms correlated well with the previous sorption experiments performed at
$10 \mathrm{mM}$ initial REE concentration and the same biomass. Not only was the highest sorption reached again for the moss, but the steepest initial slope of its isotherm implied efficient binding of the target element already at low concentrations. This suggests that $P$. patens biomass might be a suitable sorption material for flow-through cartridge systems for the recovery of metal ions from highly diluted aqueous solutions, thus helping to exploit alternative resources that are currently not accessible. Giese and Jordão (2019) found that the Langmuir isotherm model described the adsorption of $\mathrm{La}^{3+}$ on a NaOHpretreated biomass of Bacillus subtillis better, whereas Tunali and Yenigun (2021) reported for C. vulgaris and $\mathrm{Nd}^{3+}$ better correlation of the experimental data with the Freundlich isotherm. According to Febrianto et al. (2009), Langmuir's and Freundlich's isotherms are the most abundant isotherm equations in modelling adsorption data of highly heterogeneous biological adsorbent materials. Even though these empirical models are very helpful in assessing the potential of a biosorbent, they only describe the sorption properties of this adsorber for a specific metal ion. Furthermore, they describe the net effect of all mechanisms of sorption, reduction and precipitation, that specifically occur for an ion, and do not allow any further differentiation.

The binding of $\mathrm{Nd}$ by $P$. patens, C. brevissima and $C$. kessleri from solutions with various $\mathrm{pH}$ (from 1 to 6) provided further differences regarding the binding properties of the biomass. Whilst for the moss comparably high sorption was observed already at $\mathrm{pH}$ values between 3 and 6 , the binding of this REE increased linearly over the whole examined range of $\mathrm{pH}$ (1 to 6) for the cyanobacterium and the green alga and did not reach the level found for $P$. patens. This is in good agreement with the data published for brown algae by Vijayaraghavan et al. $(2010,2011)$ and Bulgariu and Bulgariu (2012). Kazak et al. (2018) tested REE sorption using several strains of heterotrophic bacteria (Microbacterium sp., Curtobacterium sp., Bacillus subtilis, Pseudomonas putida, and Bacillus pumilis) at $\mathrm{pH} 2$ and 4 and reported in each case higher sorption coefficients at higher pH. Comparably, Tunali and Yenigun (2021) found higher sorption capacities for $\mathrm{Nd}$ and C. vulgaris at $\mathrm{pH} 5$ in comparison to $\mathrm{pH} 4$ and 6. Although Minoda et al. (2015) reported efficient biosorption of $\mathrm{Nd}^{3+}, \mathrm{Dy}^{3+}$ and $\mathrm{La}^{3+}$ on the biomass of Galdieria sulphuraria from solutions with $\mathrm{pH}$ between 1.5 and 2.5 , lower sorption at low $\mathrm{pH}$ values can be explained by an increased competition between $\mathrm{Nd}$ and protons and displacement of the first by substantially smaller protons.

Comparing the acid-based titration curves with the reference curve (without biomass), protonation rates of 100, 79 and $67 \%$ were determined for C. kessleri, C. brevissima and $P$. patens, respectively, whilst PECs showed the reversed or$\operatorname{der}\left(\mathrm{PEC}_{P . \text { patens }}=3.5 \mathrm{mmol}^{*} \mathrm{~g}^{-1}, \mathrm{PEC}_{C \text {. brevissima }}=3.0\right.$ $\mathrm{mmol}^{*} \mathrm{~g}^{-1}$, PEC $\left._{C \text {. kessleri }}=2.5 \mathrm{mmol}^{*} \mathrm{~g}^{-1}\right)$. This indicates that 
the degree of protonation influences the metal sorption in the opposite direction. In comparison, Kiefer et al. (1997) reported PEC for Chlamydomonas reinhardii (green alga) and Cyclotella cryptica (diatom) of $1 \mathrm{mmol}^{*} \mathrm{~g}^{-1}$, thus at least 2.5 -fold lower than for the species examined here. Considering the PEC and higher $\mathrm{Q}_{\max }$ values for REEs determined in this work, the application of all three biomasses as biosorbents for REE recovery from wastewaters could be possible. In addition, a lower sorption capacity than expected due to the determined PEC indicates that the protonation rate of the biomass used may also have to be taken into account for such applications. At the same time, the $\mathrm{Q}_{\max }$ value reported here for $\mathrm{Au}$ and the examined moss was higher $(1.59 \pm 0.07$ $\mathrm{mmol}^{*} \mathrm{~g}^{-1}$ ) than the expected based on the hypothesis of ion exchange considering trivalent gold ions $\left(\mathrm{PEC}_{P \text {. patens }} / 3=1.2\right.$ $\mathrm{mmol}^{*} \mathrm{~g}^{-1}$ ). We thus suggest other mechanism for $\mathrm{Au}^{3+}$ removal from the solution. A plausible alternative is the reduction to elemental metals, previously described for gold and the biomass of the brown alga Fucus vesiculosus (Mata et al. 2009) or palladium and the biomass of another moss species (Racomitrium lanuginosum) (Sari et al. 2009).

Moreover, the pKa values found in this study for the investigated species are in good agreement with previous reports. For example, Chojnacka et al. (2005) published $\mathrm{pK}_{\mathrm{a}}$ values of 6.8 to 7.8 corresponding to phosphate and hydroxyl groups and $\mathrm{pK}_{\mathrm{a}}$ values of 10.8 to 11.7 for amine groups for Spirulina sp. Kiefer et al. (1997) reported $\mathrm{pK}_{\mathrm{a}}$ values of 3.2 to 4.9 for terminal carboxy groups and $\mathrm{pK}_{\mathrm{a}} 9.0$ to 9.8 for $\alpha$-amino and phenolic hydroxyl groups. Slight differences in the pKa values for the same functional groups can most probably be explained by different chemical surroundings as well as different dissociation patterns in the various matrices. Nevertheless, all these functional groups can participate in proton-to-metal-ionexchange at different $\mathrm{pH}$ conditions.

In addition, carboxy and hydroxy groups, which play an exceptional role in proton-to-metal-ion-exchange, seem to appear at various $\mathrm{pK}_{\mathrm{a}}$ values in the here examined species, thus pointing to different chemical surroundings and different dissociation patterns. This can in turn explain differences in sorption capacities of the three species at different $\mathrm{pH}$ values. Finally, most wastewater samples, where higher concentration of REEs can be expected, have $\mathrm{pH}$ values less than or equal to three. At this $\mathrm{pH}$, all functional groups discussed here are fully protonated resulting in increased proton-to-metal-exchange abilities of the biomasses.

In summary, interesting results regarding biosorption properties of three different biological species (a moss $P$. patens, a cyanobacterium $-C$. brevissima, and a green alga - C. kessleri) for REEs and other precious and possibly biosorption influencing metal ions are shown in this work. The highest binding capacity for REEs and gold was registered for $P$. patens, which makes this species particularly interesting for the application as a biosorber. However, we also report surprisingly different biosorption capacities for this species depending on the cultivation mode. Thus, further studies are needed to better assess the potential of $P$. patens as a biosorber for REEs. Moreover, the modelling of the biosorption mechanisms of $\mathrm{Nd}^{3+}$ to the biomass of $P$. patens should be carried out, for a better understanding of this processes and to develop practical applications. Furthermore, when considering biomass as biosorber for industrial applications not only biosorption of the target elements itself but also the productivity of the biomass in the required cultivation mode must be considered for evaluating its feasibility. Finally, kinetic studies of the selective binding of the target metal ions from multicomponent solutions have to be performed to enable a development of the intended biosorptionbased recovery of the high value metal ions. Therefore, selectivity investigations must be conducted for mimicking of the binding from environmental samples and an advanced understanding of binding properties and biosorption mechanisms of selected biological species should be forced.

Acknowledgements We would like to thank Dr Nicola Taccardi (Institute of Chemical Reaction Engineering, Friedrich-Alexander University of Erlangen-Nürnberg, Germany) for providing ICP-AES measurements and chemical digestion experiments, and Prof Dr Nicolai Burzlaff and Marleen Mayer (Department of Chemistry and Pharmacy, Friedrich-Alexander University Erlangen-Nürnberg, Germany) for the FT-IR measurements. Additional acknowledgments are directed to Prof Dr Rainer Buchholz who enabled research on this topic at the Institute of Bioprocess Engineering, Friedrich-Alexander University ErlangenNürnberg.

Code availability Not applicable

Author contribution $\mathrm{MH}, \mathrm{RB}$ and $\mathrm{AMB}$ conceived and designed research. MH conducted experiments. $\mathrm{MH}$ and AMB analysed data. $\mathrm{MH}$ wrote the manuscript. All authors provided critical feedback and helped shape the research, analysis and manuscript. All authors read and approved the manuscript.

Funding Open access funding enabled and organized by Projekt DEAL. This work was part of the ForCYCLE I project group for greater resource efficiency in Bavarian industry research and was funded by the Bavaria State Ministry of the Environment and Consumer Protection (grant number: BAF01SoFo-66947).

Data availability The data that support the findings of this study are available from the corresponding author upon reasonable request.

\section{Declarations}

Ethics approval This article does not contain any studies with human participants or animals performed by any of the authors.

Consent to participate Not applicable

Consent for publication Not applicable 
Competing interests The authors declare no competing interests.

Open Access This article is licensed under a Creative Commons Attribution 4.0 International License, which permits use, sharing, adaptation, distribution and reproduction in any medium or format, as long as you give appropriate credit to the original author(s) and the source, provide a link to the Creative Commons licence, and indicate if changes were made. The images or other third party material in this article are included in the article's Creative Commons licence, unless indicated otherwise in a credit line to the material. If material is not included in the article's Creative Commons licence and your intended use is not permitted by statutory regulation or exceeds the permitted use, you will need to obtain permission directly from the copyright holder. To view a copy of this licence, visit http://creativecommons.org/licenses/by/4.0/.

\section{References}

Ambaye TG, Vaccari M, Castro FD, Prasad S, Rtimi S (2020) Emerging technologies for the recovery of rare earth elements (REEs) from the end-of-life electronic wastes: a review on progress, challenges, and perspectives. Environ Sci Pollut Res 27:36052-36074. https://doi. org/10.1007/s11356-020-09630-2

Andrès Y, Texier AC, Le Cloirec P (2003) Rare earth elements removal by microbial biosorption: a review. Environ Technol 24(11):13671375. https://doi.org/10.1080/09593330309385681

Bulgariu D, Bulgariu L (2012) Equilibrium and kinetics studies of heavy metal ions biosorption on green algae waste biomass. Bioresour Technol 103(1):489-493

Chojnacka K, Chojnacki A, Górecka H (2005) Biosorption of $\mathrm{Cr}^{3+}, \mathrm{Cd}^{2+}$ and $\mathrm{Cu}^{2+}$ ions by blue-green algae Spirulina $s p$. : kinetics, equilibrium and the mechanism of the process. Chemosphere 59(1):75-84. https://doi.org/10.1016/j.chemosphere.2004.10.005

European Commission (2017) Communication from the Commission to the European Parliament, the Council, The European Economic and Social Committee and the Committee of the Regions on the list of critical low materials for the EU. https://eur-lex.europa.eu/legalcontent/EN/TXT/?uri=CELEX:52017DC0490 Accessed on 17.02. 2021.

Febrianto J, Kosasih AN, Sunarso J, Ju J-H, Indraswati N, Ismadji S (2009) Equilibrium and kinetic studies in adsorption of heavy metals using biosorbent. A summary of recent studies. J Hazard Mat 162: 616-645. https://doi.org/10.1016/j.jhazmat.2008.06.042

Freundlich HMF (1906) Over the adsorption in solution. J Phys Chem 57: $385-470$

Giese EC (2020) Biosorption as green technology for the recovery and separation of rare earth elements. World J Microbiol Biotechnol 36(4):1-11. https://doi.org/10.1007/s11274-020-02821-6

Giese EC, Jordão CS (2019) Biosorption of lanthanum and samarium by chemically modified free Bacillus subtilis cells. Appl Water Sci 9(8):1-8. https://doi.org/10.1007/s13201-019-1052-3

Gonzalez AG, Pokrovsky OS, Beike AK, Reski R, Di Palma A, Adamo P, Giordano S, Fernandez JA (2016) Metal and proton adsorption capacities of natural and cloned Sphagnum mosses. J Colloid Interface Sci 461:326-334

Gupta VK, Bhushan R, Nayak A, Singh P, Bhushan B (2014) Biosorption and reuses potential of a blue green alga for the removal of hazardous reactive dyes from aqueous solutions. Bioremed J 18(3):179-191. https://doi.org/10.1080/10889868.2014.918574

Guyonnet D, Planchon M, Rollat A, Escalon V, Tuduri J, Charles N, Vaxelaire S, Dubois D, Fargier H (2015) Material flow analysis applied to rare earth elements in Europe. J Clean Prod 107:215 228. https://doi.org/10.1016/j.jclepro.2015.04.123
Heilmann M, Jurkowski W, Buchholz R, Brueck T, Becker AM (2015) Biosorption of neodymium by selected photoautotrophic and heterotrophic species. J Chem Eng Process Technol 6(4):1. https://doi. org/10.4172/2157-7048.1000241

Heining M (2016) Dissertation: Interne Beleuchtung von Photobioreaktoren mittels Wireless Light Emittern. urn:nbn:de: bvb:29-opus4-72825 Accessed on 19.05.2021

Heining M, Sutor A, Stute SC, Lindenberger CP, Buchholz R (2015) Internal illumination of photobioreactors via wireless light emitters: a proof of concept. J Appl Phycol 27(1):59-66. https://doi.org/10. 1007/s10811-014-0290-x

Humphries M (2013) Rare earth elements: the global supply chain. CRS Report for Congress R41347: 1-27. https://fas.org/sgp/crs/natsec/ R41347.pdf Accessed on 17.02.2021.

Itouga M, Hayatsu M, Sato M, Tsuboi Y, Kato Y, Toyooka K, Suzuki S, Nakatsuka S, Kawakami S, Kikuchi J, Sakakibara H (2017) Protonema of the moss Funaria hygrometrica can function as a lead $(\mathrm{Pb})$ adsorbent. PLoS One 12(12):e0189726. https://doi.org/10. 1371/journal.pone.0189726

Kazak ES, Kalitina EG, Kharitonova NA, Chelnokov GA, Elovskii EV, Bragin IV (2018) Biosorption of rare-earth elements and yttrium by heterotrophic bacteria in an aqueous environment. Mosc Univ Geol Bull 73(3):287-294. https://doi.org/10.3103/S0145875218030043

Khataee AR, Vafaei F, Jannatkhah M (2013) Biosorption of three textile dyes from contaminated water by filamnetous green algal Spirogyra $s p$.: Kinetik, isotherm and thermodynamic studies. Int Biodeterior Biodegradation 83:33-40. https://doi.org/10.1016/j.ibiod.2013.04. 004

Kiefer E, Sigg L, Schosseler P (1997) Chemical and spectroscopic characterization of algae surfaces. Environ Sci Technol 31:759-764. https://doi.org/10.1021/es960415d

Kłos A, Gordzielik E, Jóźwiak MA, Rajfur M (2014) Sorption of cadmium and zinc in selected species of epigeic mosses. Bull Environ Contam Toxicol 92(3):323-328. https://doi.org/10.1007/s00128014-1210-0

Kücüker MA, Wieczorek N, Kuchta K, Copty NK (2017) Biosorption of neodymium on Chlorella vulgaris in aqueous solution obtained from hard disk drive magnets. PLoS One 12(4):e0175255. https:// doi.org/10.1371/journal.pone.0175255

Kuyucak N, Volesky B (1988) Biosorbents for recovery of metals from industrial solutions. Biotechnol Lett 10(2):137-142

Langmuir I (1932) Surface chemistry. Nobel Lecture:287-325

Martins RJ, Pardo R, Boaventura RA (2004) Cadmium (II) and zinc (II) adsorption by the aquatic moss Fontinalis antipyretica: effect of temperature, $\mathrm{pH}$ and water hardness. Water Res 38(3):693-699. https://doi.org/10.1016/j.watres.2003.10.013

Mata YN, Torres E, Blázques ML, Ballester A, Gonzáles F, Muñoz JA (2009) Gold(III) biosorption and bioreduction with the brown alga Fucus vesiculosus. J Hazardous Mat 166(2-3):612-618

Minoda A, Sawada H, Suzuki S, S-i M, Inagaki K, Yamamoto T, Tsuzuki M (2015) Recovery of rare earth elements from the sulfothermophilic red alga Galdieria sulphuraria using aqueous acid. Appl Microbiol Biotechnol 99(3):1513-1519. https://doi.org/10. 1007/s00253-014-6070-3

Ojima Y, Kosako S, Kihara M, Miyoshi N, Igarashi K, Azuma M (2019) Recovering metals from aqueous solutions by biosorption onto phosphorylated dry baker's yeast. Sci Rep 9(1):1-9. https://doi. org/10.1038/s41598-018-36306-2

Öko-Institut e.V (2011) Hintergrundpapier Seltene Erden. https://www. oeko.de/fileadmin/pdfs/oekodoc/1110/2011-001-de.pdf Accessed on 19.05.2021.

Okoli CP, Diagboya PN, Anigbogu IO, Olu-Owolabi BI, Adebowale KO (2017) Competitive biosorption of $\mathrm{Pb}$ (II) and $\mathrm{Cd}$ (II) ions from aqueous solutions using chemically modified moss biomass (Barbula lambarenensis). Environ Earth Sci 76:33. https://doi.org/10.1007/ s12665-016-6368-9 
Oliveira RC, Garcia O Jr (2009) Study of biosorption of rare earth metals ( $\mathrm{La}, \mathrm{Nd}, \mathrm{Eu}, \mathrm{Gd}$ ) by Sargassum sp. biomass in batch systems. Advanced Mat Res 71-73:605-608. https://doi.org/10.4028/www. scientific.net/AMR.71-73.605

Palmieri MC, Garcia O, Melnikov P (2000) Neodymium biosorption from acidic solutions in batch system. Process Biochem 36 (5) 441-444. https://doi.org/10.1016/S0032-9592(00)00236-3

Ruangsomboon S, Aue-Umneoy D, Saparnklang A (2013) Biosorption of basic dye, malachite green by brown alga Padina sp. In Proceedings of the 2nd International Conference on Integration of Science and Technology for Sustainable Development (ICIST) (pp. 28-29).

Sari A, Medil D, Tuzen M, Soylak M (2009) Biosorption of palladium(II) from aqueous solution by moss (Racomitrium lanuginosum) biomass: equilibrium, kinetic and thermodynamic studies. J Hazardous Mat 162(2-3):874-879

Tunali M, Yenigun $\mathrm{O}$ (2021) Biosorption of $\mathrm{Ag}^{+}$and $\mathrm{Nd}^{3+}$ from singleand multi-metal solutions $\left(\mathrm{Ag}^{+}, \mathrm{Nd}^{3+}\right.$, and $\left.\mathrm{Au}^{3+}\right)$ by using living and dried microalgae. J Mater Cycles Waste Manag 23(2):764-777. https://doi.org/10.1007/s10163-020-01168-2

Turner BF, Fein JB (2006) ProtoFit: a program for determining surface protonation constants from titration data. Comput Geosci 32:1344 1356. https://doi.org/10.1016/j.cageo.2005.12.005

US Department of Interior (2018) 83 FR 23295 - final list of critical minerals 2018. Office of the Federal Register. National Archives and Records Administration 83(97):23295-23296
Veglio F, Beolchini F (1997) Removal of metals by biosorption: a review. Hydrometallurgy 44(3):301-316

Vijaraghavan J, Bhagavathi Pushpa T, Sardhar Basha SJ, Vijaraghavan K, Jegan J (2015) Evaluation of red marine alga Kappaphycus alvarezii as biosorbent for methylene blue: isotherm, kinetic, and mechanism studies. Sep Sci Technol 50(8):1120-1126. https://doi. org/10.1080/01496395.2014.965260

Vijayaraghavan K, Sathishkumar M, Balasubramanian R (2010) Biosorption of lanthanum, cerium, europium, and ytterbium by a brown marine alga, Turbinaria Conoides. Ind Eng Chem Res 49: 4405-4411. https://doi.org/10.1021/ie1000373

Vijayaraghavan K, Sathishkumar M, Balasubramanian R (2011) Interaction of rare earth elements with a brown marine alga in multi-component solutions. Desalination. 265(1-3):54-59. https:// doi.org/10.1016/j.desal.2010.07.030

Wilke A, Buchholz R, Bunke G (2006) Selective biosorption of heavy metals by algae. Environ Biotechnol 2(2):47-56

Zhang Y, Banks C (2005) The interaction between $\mathrm{Cu}, \mathrm{Pb}, \mathrm{Zn}$ and Ni in their biosorption onto polyurethaneimmobilised Sphagnum moss. J Chem Technol Biotechnol 80(11):1297-1305. https://doi.org/10. $1002 /$ jctb.1329

Publisher's note Springer Nature remains neutral with regard to jurisdictional claims in published maps and institutional affiliations. 